\title{
Structural Equation Modelling Of Predictors Of Pupils' Achievement In Mathematics In Niger Delta, Nigeria
}

\author{
${ }^{1}$ Benson Adesina Adegoke $\mathrm{PhD}$ and ${ }^{2}$ Veronica O. Amatari \\ Institute of Education, University of Ibadan, Nigeria
}

\begin{abstract}
In this article, the authors examined the direct and indirect effects of geo-economic factors, parental involvement and proficiency in English language on primary school pupils' achievement in mathematics. The sample comprised 216 primary six pupils randomly selected from 10 primary schools in Ethiope East Local Government Area of Delta state, Nigeria. Five validated instruments were used to collect data. Analysis showed that parental involvement as well as pupils' proficiency in English language had direct effects on mathematics achievement. Although geo-economic factors had no direct effect on mathematics achievement, environmental degradation as being witnessed in the Niger Delta Region of Nigeria impacts negatively on the level of parental involvement in their children's education. The findings of this study show that parents should be encouraged to be more involved in their children education. More importantly, policies that will reduce oil spillage and other environmental hazards associated with oil exploration in the Niger Delta region should be vigorously pursued. Keywords: Environmental degradation; Poverty; at-home parental involvement; at-school parental involvement; Mathematics achievement; Proficiency in English Language
\end{abstract}

\section{Introduction}

Primary education is the foundation upon which other levels of education are laid and it is best described as the key to the success or failure of the whole educational system. Generally, the goals of primary education include inculcation, in the child, permanent literacy, and numeracy, and ability to communicate effectively; laying sound basis for scientific and reflective thinking; giving the child opportunities for developing manipulative skills that will enable him or her function effectively in the society within the limits of his or her capacity. These basic goals are reflected in the national policy on education of many countries. For example, the National Policy on Education of the Federal Republic of Nigeria (FRN, 2004) reflects these basic goals.

To achieve these goals, government at the state and federal levels in Nigeria, employs teachers, build schools, and provide free textbooks in some cases to primary school pupils. However, the Federal Government of Nigeria welcomes and has policy which encourages the participation of parents in fostering the academic progress of their children. In her efforts at enhancing the right of the child to education (Child's Right Act, 2003), the Federal Government of Nigeria enacted the Universal Basic Education Commission (UBEC) Act in 2004. One of the fundamental provisions of the Act is that every parent/guardian should ensure that his/her child/ward attend and complete primary/junior secondary school education and failure to comply shall attract sanctions. The Act further states that all stakeholders in education in a local government should ensure that every parent/person who has the care and custody of a child performs this duty.

Parental involvement in the child's education according to Abd-El-Fattah (2006) is a mechanism for raising standards, developing new partnerships between schools and parents in the local community, and promoting social inclusion. Parental involvement (Abd-El-Fattah, 2006) also refers to parents' behavior at home and at school intended to assist the children's overall learning experiences. These include helping with the child's home work, buying textbooks and attending parents - teachers' association meetings and visiting the schools especially on open days to have first hand information about the child's learning experiences.

Literature (Howley and Maynard, 2006; Kloosterman, Notten, Tolsma, Kraaykamp, 2011; Olatoye and Agbatogun, 2009; Van Voorhis, 2003) has established linkage between parents' involvement in children's education and higher academic achievement of those children. For example, Van Voorhis (2003) reported that children achieved at higher levels in school work when parents offered assistance in school homework. Epstein's (2001) work found out that children at all grade levels do better in academic work and have more positive behaviors if they have parents who are aware, knowledgeable, encouraging and involving. Research suggests that children whose parents are involved during the crucial developmental stages of preschool and early school years, often experience success, not just in school but throughout life (Kloosterman, Notten, Tolsma, Kraaykamp, 2011; Olatoye and Agbatogun, 2009). Howley and Maynard (2006) posited that parents who help and encourage their children to learn at home and who help develop positive attitudes toward school contribute to the personal growth and academic success of their children. 
Although research has shown that when parents participate fully in the child's education, the child tends to perform better in academic work, research (such as Honig, Kahne and McLaughlin, 2001; Jordan, Orozco, \& Averret, 2001) has also shown that some factors can equally hinder parental involvement in the child's education. Studies show that social coherence, neighborhood stability and character of the communities from which students are drawn are some of these factors. The character of the community may be determined by policies dealing with geo-economic and political developments (Jordan et al, 2001).

The Niger Delta, where this study took place is a densely populated region which extends over $70,000 \mathrm{~km}^{2}$ and makes up 7.5\% of Nigeria's landmass. It is made up of the oil producing Niger Delta comprising nine oil producing states of Rivers, Bayelsa, Delta, Cross Rivers, Akwa Ibom, Edo, Abia, Imo and Ondo States. The 2006 United Nation Development Programme (UNDP) Niger Delta Human Development Report analysed the amazing paradoxes of the Niger Delta as a region with enormous resources accounting for "upward of 80 percent of Nigeria's exchange earnings and about 70 percent of government revenue" yet "suffering from administrative neglect, crumbling social infrastructure, and services, high unemployment, social deprivation, abject poverty, filth and squalor and endemic conflict" (Pg. 9).

Environmental degradation is a major cause of productivity losses and poor human health in the Niger Delta (Ibaba, 2010). The devastation of the environment and ecological balance by oil and gas exploitation in the region has multidimensional implications for the people of the region: water pollution which is majorly induced by oil spillage; communities' shore lines washed away or eroded due to the high volume of deep sea exploration and exploitation activities; destruction of fresh water ecological systems as a result of constructed canals by oil companies; degradation of forests and depletion of aquatic fauna, which were caused by oil induced fire and pollution of the environment; air pollution induced by gas flaring; health issues including breathing problems and skin lesions.

The Niger Delta region is dominated by rural communities that depend solely on the natural environment for subsistence living. More than seventy percent of the people depend on natural environment for living and non living livelihood (UNDP Report, 2006). Oil production, gas extraction and its attendant consequences for the declining productivity of the region which is predominantly based on fisheries and other agricultural activities as farming, lumbering, palm oil milling, palm wine tapping is of high magnitude (Eregha and Irughe, 2009; Opukri and Ibaba, 2008). The UNDP Report (2006) argued that before the advent of oil in commercial quantities; the production of palm oil, palm kernel and timber earned considerable income for the region and Nigeria. But the loss of the once vibrant agricultural and fishing sectors and very limited access to the benefits from oil resources set the stage for violence in the region.

Furthermore, high incidence of poverty in the face of existence of incredible wealth in the region is ironic. The UNDP Report states: "Poverty has become a way of life due to economic stagnation, agricultural underdevelopment from soil infertility; unemployment; poor quality of life due to shortages of essential goods, facilities and money; isolation and poor communication, government insensitivity; and an unhealthy environment spreading disease and malnutrition" (2006: 36-37). The report indicated clearly that "oil wealth enriches Nigeria as a country but it has not alleviated the grinding poverty, neglect and deprivation in the region that produces it". The Word Bank's (2004) clarification of poverty is that: "poverty is hunger; poverty is lack of shelter; poverty is being sick and not being able to see a doctor; poverty is not being able to go to school and not knowing how to read; poverty is not having a job, is fear for the future, living one day at a time; poverty is losing a child to illness brought about by unclean water; poverty is powerlessness, lack of representation and freedom". Ekpenyong, Ukommi and Agha (2010) averred that the poverty in the Niger Delta region is evident in mass unemployment and the inability of the oil multinationals and the Nigerian government to provide adequate welfare services and infrastructural and human development.

Poverty limits parents' ability to provide for their children and augment their children's education with resources in home. In corroboration, George and Mensah (2010) affirmed that poverty exerts direct effects on parents' mental health and self-perceptions through increased stress resulting from the struggle to make ends meet. These parents, in their daily struggle to survive in the face of the multiplier effects of the geo-economic factors that are prevalent in the Niger Delta, are more likely to give little or no attention to the educational development of their children and place low value on education. This probably could have contributed to the poor academic achievement of pupils from the region in public examinations being conducted by the Federal Ministry of Education. For example, while primary six pupils from other zones of Nigeria (e.g. South West and South East) need a minimum of $75 \%$ pass in Mathematics and English in common entrance examinations into Federal Government Colleges, most states in the Niger Delta region e.g. Bayelsa needs as low as 55\% (National Examination Council Report, 2008).

Although research in the Niger Delta has shown that massive oil exploration has impacted negatively on the socio-economic and environmental conditions of the people, there is no empirical evidence that this influences the parental involvement on the child's education. Very few studies, in fact if there is any, has shown how parental involvement mediates the relationship between environmental conditions of the Niger Delta 
Region and pupils' achievement in Mathematics and English Language. The importance of language of instruction on pupils' mathematics achievement in schools is well documented in literature. The correlation between English language and Mathematics has been found to be high and positive (Adegoke and Ibode 2007; Fakeye and Ogunsiji, 2009). The knowledge of the contents of school subjects like Mathematics is transferred to the students at all levels of education via English language medium. It therefore follows that how well pupils would fare in academic attainment in primary school Mathematics depends largely on their level of proficiency in English language. However, very few studies have shown how it mediates the relationship between parental involvement and mathematics achievement. It is on the basis of this that this study examined the extent to which geo-environmental conditions affect parental involvement in child' education and how the relationship consequently affects pupils' achievement in Mathematics through pupils' proficiency in English Language.

The Niger Delta Region is inhabited by a large number of different ethnic groups each ranging from a few thousands to many millions. Each of these ethnic groups has distinct language which members of the group use to communicate with one another. As a result of the multiplicity of languages, besides English language, Pidgin English which is a form of corrupt English Language has been adopted as a lingual Franca in informal domains in the Niger Delta Region. It is used in literary or creative writing, in mass media, and inter-ethnic communications. In schools teachers and pupils in primary schools communicate with one another by using Pidgin English. In fact it functions as a language of wider communication in public institutions (Omoniyi, 2012).

Epstein's (1995) model of parental involvement is adopted as the theoretical framework for this study. It is based on a Social Organisation perspective of overlapping influence, emphasizing that children are best supported when families and schools have shared goals and work collaboratively. It emphasize that families, schools and communities are jointly responsible for and influential in children's development and that when the child is best supported he or she is likely to perform better in school. Epstein's model as shown in Figure 1 views school, family and community relations as dynamic, in that their overlapping spheres can be pushed together or pulled apart by important forces: background and practices of families, schools and communities; developmental characteristics of students; historical and policy contexts and time (Epstein \& Sanders, 2000). When pulled together the child succeeds in school and when pulled apart, the child fails in school academic work.

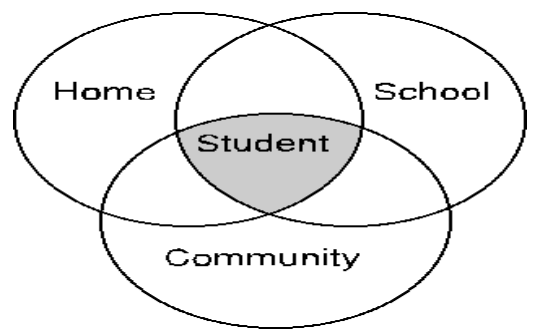

Figure 1: The Overlapping Spheres of Influence: Home, School and Community

In order to place this study in a very clear perspective, the authors developed a Path Analysis (PA) model. PA is a variant of structural equation models. The other examples are Structural Regression (SR) and Confirmatory Factor Analysis (CFA) models.

The hypothesized structural PA model of the relationship is shown in figure 2.

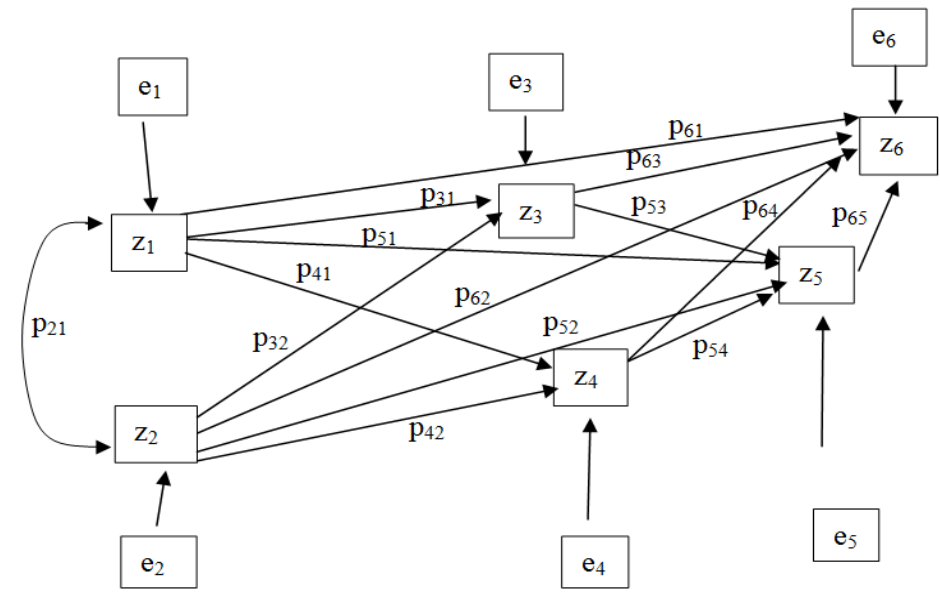

Figure 2: Hypothesized structural Path Analysis Model 
Note: $\mathrm{z}_{1}=$ environmental degradation; $z_{2}=$ poverty; $z_{3}=$ at-home parental involvement; $z_{4}=$ at-school parental involvement; $z_{5}=$ achievement in English Language; $z_{6}=$ Achievement in Mathematics; $e_{1} ; e_{2} ; e_{3} ; e_{4} ;$ and $e_{4}$ represent errors.

The structural equations for the hypothesized model are:

$\mathrm{z}_{1}=\mathrm{e}_{1}$

$\mathrm{z}_{2}=\mathrm{e}_{2}$

$\mathrm{z}_{3}=\mathrm{p}_{31} \mathrm{z}_{1}+\mathrm{p}_{32} \mathrm{z}_{2}+\mathrm{e}_{3}$

$\mathrm{z}_{4}=\mathrm{p}_{41} \mathrm{z}_{1}+\mathrm{p}_{42} \mathrm{z}_{2}+\mathrm{p}_{43} \mathrm{z}_{3}+\mathrm{e}_{4}$

$\mathrm{z}_{5}=\mathrm{p}_{51} \mathrm{z}_{1}+\mathrm{p}_{52} \mathrm{z}_{2}+\mathrm{p}_{53} \mathrm{z}_{3}+\mathrm{p}_{54} \mathrm{z}_{4}+\mathrm{e}_{5}$

$\mathrm{z}_{6}=\mathrm{p}_{61} \mathrm{z}_{1}+\mathrm{p}_{62} \mathrm{z}_{2}+\mathrm{p}_{63} \mathrm{z}_{3}+\mathrm{p}_{64} \mathrm{z}_{4}+\mathrm{p}_{65} \mathrm{z}_{5}+\mathrm{e}_{6}$

The structural equations show that environmental degradation and parents' poverty level were taken as the exogenous variables. The other variables: at-home parental involvement, at-school parental involvement, proficiency in English language and mathematics achievement were the endogenous variables. However, the main criterion variable examined in this study was pupils' achievement in mathematics for which other endogenous variables serve as a link to geo-economic factors.

In this study, the researcher answered the following questions:

1) What type of correlations exists among geo-economic factors (environmental degradation and poverty), parental involvement (at-home involvement and at-school involvement), pupils' proficiency in English Language and mathematics?

2) What are the fit indices of the model?

3) What are the estimated direct, indirect, and total causal effects among the variables?

\section{Participants}

\section{Methodology}

The participants were 216 primary six pupils randomly drawn from 10 primary schools in the rural areas of oil producing communities in Delta States. Among the 216 students sampled, $132(61.1 \%)$ were boys, while $84(39.9 \%)$ were girls. Their ages ranged between 10 and 12 years (Mean age $=11.43 ; \mathrm{SD}=1.08$ ).

Materials

For this survey, five instruments were used. These are:

a) Parental Involvement Questionnaire (PIQ)

b) Environmental Degradation Survey (EDS)

c) Poverty Questionnaire (PQ)

d) Pupils' English Achievement Test (PEAT)

e) Pupils' Mathematics Achievement Test (PMAT)

PIQ: It was constructed by the second author of this article Amatari V.O. Parents of the child responded to this questionnaire. It consists of two sections: A and B. Section A seeks background information on gender, name of the community, relationship with the child, and name of child. In section B, two subscales of the PIQ were used to assess level of parental involvement in child's education. These subscales were at-home involvement, and atschool involvement.

\section{At-home involvement}

This section had 30 items. Examples of items include: I discuss activities that take place in school with my child; I provide text books for my child. Each item was scored on a 4 - point Likert scale ranging from 1 (Never) to 4 (Very often). Scores of at-home involvement could range from 30 (low level of at-home parental involvement) to 120 (high level of at-home parental involvement). Cronbach alpha method was used to establish the internal consistency of the 30 items. Analysis yielded 0.81 .

\section{At-school involvement}

This section had 15 items. Examples of items include: I participate in the activities of Parent-Teacher Association; I attend school's open days. Each item was scored on a 4 - point Likert scale ranging from 1 (Never) to 4 (Very often). Scores of at-school involvement could range from 15 (low level of at-school parental involvement) to 60 (high level of at-school parental involvement). Cronbach alpha method was used to establish the internal consistency of the 15 items. Analysis yielded 0.84 .

$E D S$ : It was developed by the first author of this article. Parents responded to this survey. It consists of two sections: A and B. Section A seeks background information on age, gender, state and name of community and name of the child. Section B contains 21 items on a 3-point scale of (1) low, (2) moderate and (3) high. Examples of items in EDS include: oil exploration has reduced the fertility of our land; oil exploration has reduced the aquatic live in our rivers. Score could range from 21 (lowest score) to 63 (highest score). The 
internal consistency of EDS was determined by subjecting the parents' responses to Cronbach alpha statistical analysis which yielded 0.87 .

$P Q$ : It was developed by the two authors of this article. It comprises two sections: A and B. Section A covers the various types of occupation predominant in the Niger Delta region and Section B contains 21 statement items on indices of poverty. Examples of items include: What type of house do you live in; what is you income level per annum:

PMAT: It was developed by the two authors of this article. It consists of 30 multiple choice test items with 4 options (ABCD) per item. Items were based on Mathematics curriculum developed by National Educational Research and Development Council, Abuja (NERDC, 1995). We developed these items from three major sections of mathematics: Algebra, Geometry, and Statistics. Initially there were 47 items. These items were subjected to pilot testing among 30 primary six pupils in Ahoada local Government Area of Rivers State. Seventeen items whose difficulty indices ranged between 0.21 and 0.47 were deleted. For the remaining 30 items the difficulty indices of each item ranged between 0.50 and 0.75 , while the discriminating indices ranged between 0.43 and 0.65 . The reliability index of PMAT was 0.71 . This was established by using Kuder Richardson 20 formular. The maximum obtainable score in PMAT was 30, that is, each item attracted a score of 1. The content validity of PMAT was ensured by using table of specification placed under knowledge, understanding and thinking.

PEAT: This instrument consists of multiple choice 30 items with 4 options (ABCD) per item. These items were developed from three major sections of English language (Comprehension, Lexis and structure, and Grammar) as prescribed by the National Educational Research Council, Abuja (NERDC, 1995). Initially there were 55 items. These items were subjected to pilot testing among 30 primary six pupils in Ahoada local Government Area of Rivers State. Twenty five items whose difficulty indices ranged between 0.23 and 0.42 were deleted. For the remaining 30 items the difficulty indices of each item ranged between 0.52 and 0.75 , while the discriminating indices ranged between 0.46 and 0.61 . The reliability index of PEAT was 0.79 . This was established by using Kuder Richardson 20 formular. The maximum obtainable score was 30, that is, each item attracted a score of 1 . The content validity of PEAT was ensured by using table of specification placed under knowledge, understanding and thinking.

\section{Procedure}

Two research assistants, three local hands as well as the second author were involved in the collection of data.

Three days were used to administer and to retrieve the PEAT and PMAT instruments from the pupils across the selected ten public primary schools. The administration of each of the achievements tests took place during the normal time scheduled for subject on the official school time table. This was to avoid disruption of the school programmes. For PMAT, the pupils completed it on the average, in 62 minutes, though the time allowed was 70 minutes. For PEAT the students completed them in about 65 minutes though the maximum time allowed was 70 minutes. For the administration of instruments meant for the parents the local hands recruited helped in the translation of the content of the instruments to the illiterate parents from compound to compound. Responses from the parents were ticked as applicable by the translator. These local hands are the indigenes of the community that are educated and proficient in the language of the immediate environment. They also assisted in enlightening the parents on the objective of the study before the administration of the instrument. In all, the administration of the instruments took nine days.

The data collected were analysed using LISREL Version 8.80 (Linear Structural Relations; Jöreskog \&

Sörbom, 2006). The model fit statistics and other estimates were calculated using the maximum likelihood estimate of LISREL.

\section{Results}

The descriptive statistics (Pearson Correlation coefficient, mean, and standard deviation) were calculated using LISREL Version 8.80. Also variance-covariance statistics were obtained. Table 1 presents the Pearson product-moment correlation coefficients between the variables. Mean and standard deviations of each of the six variables are as presented on the table. Table 2 shows the variance-covariance matrix.

Table 1: Pearson correlation coefficient, mean, and standard deviation

\begin{tabular}{|r|c|c|c|c|c|c|}
\hline Variables & ENV & POV & ATH & ATS & ENG & MAT \\
\hline ENV & 1.000 & & & & & \\
\hline POV & .101 & 1.000 & & & & \\
\hline ATH & $-.165^{*}$ & $.146^{*}$ & 1.000 & & & \\
\hline ATS & -.091 & .003 & $.402^{*}$ & 1.000 & & \\
\hline ENG & .029 & .104 & $.305^{*}$ & -.040 & 1.000 & \\
\hline
\end{tabular}


Structural Equation Modelling Of Predictors Of Pupils’ Achievement In Mathematics In Niger Delta,

\begin{tabular}{|r|c|c|c|c|c|r|}
\hline MAT & -.071 & .049 & $.294^{*}$ & $.241^{*}$ & $.508^{*}$ & 1.000 \\
\hline Mean & 41.85 & 47.38 & 90.75 & 37.98 & 12.40 & 10.00 \\
\hline SD & 8.46 & 9.71 & 11.37 & 6.23 & 5.64 & 3.33 \\
\hline
\end{tabular}

* Correlation is significant at the 0.05 level (2-tailed).

Table 2 shows the variance-covariance matrix.

Table 2: Variance-Covariance matrix of geo-economic factors, parental involvement pupils' achievement in English Language and mathematics

\begin{tabular}{|r|c|c|r|r|r|r|}
\hline Variables & ENV & POV & ATH & ATS & ENG & MAT \\
\hline ENV & 1.00 & & & & & \\
\hline POV & .10 & 1.00 & & & & \\
\hline ATH & -.17 & .15 & 1.00 & & & \\
\hline ATS & -.09 & .00 & 0.40 & 1.00 & & \\
\hline ENG & .03 & .10 & 0.30 & -.04 & 1.00 & \\
\hline MAT & -.09 & .02 & 0.28 & .27 & .51 & 1.00 \\
\hline
\end{tabular}

Research Question One: What type of correlation exists among geo-economic factors (environmental degradation and poverty), parental involvement (at-home involvement and at-school involvement), pupils' proficiency in English Language and mathematics?

To answer this research question, we examined the correlation coefficient in Table 1. Figures in the Table shows that while some of the variables are moderately and significantly correlated with one another, in some cases the correlation is both low and statistically not significant. The highest correlation $(\mathrm{r}=.508)$ is between at mathematics achievement and English Language. The lowest correlation $(r=.003)$ is between atschool parental involvement and poverty. The table shows that environmental degradation correlates negatively with at-home parental involvement. It is quite interesting to note that the correlation is statistically significant. Poverty correlates positively with at-home involvement and the relationship is positive. Table 1 also shows that the pupils' level of performance in English language is slightly better than their performance in mathematics. More importantly, from the maximum likelihood estimates, the independence model Chi square analysis shows that the variables are correlated $\chi^{2}(15, \mathrm{~N}=216)=166.18, \mathrm{p}<0.05$.

Research Question Two: What are the fit indices of the model?

From the maximum likelihood estimates, the overall fit of the model was poor, only marginal support was found for the hypothesized model $\chi^{2}(1, \mathrm{~N}=216)=36.93, \mathrm{p}<0.05$. In a good model fit situation, the hypothesized model Chi Square statistics should not be significant. Other fit indices were also examined. These include: Root-Mean-Square-Error of Approximation (RMSEA) $=0.39$ with the $90 \%$ Confidence interval $(0.29$ 0.51); Comparative Fit Index $(\mathrm{CFI})=0.75$; Normed Fit Index $(\mathrm{NFI})=0.77$; and Parsimony Goodness of Fit Index $(\mathrm{PGFI})=0.05$. These values indicate overall poor model fit (See, Hu and Bentler, 1999; Kline, 2005).

However because of the observed relationship among the variables, as assessed by Pearson Moment correlation coefficients and independence model Chi Square statistics, it is important to assess the significance of direct and indirect effects of environmental degradation, poverty level, at home and at school parental involvement on pupils' achievement in English Language and Mathematics.

Research Question Three: If the model fit is perfect what are the estimated direct, indirect, and total causal effects among the variables?

The estimated direct, indirect and total causal effects are the model parameter estimates.

\section{Direct Effects}

The direct effects are given by the standardized path coefficients obtained from the maximum likelihood estimates. They function as beta weights (ß) in multiple regression analysis.

With regard to the direct effects, the test statistic is the critical ratio, which represents the parameter estimate divided by its standard error, as such; it operates as a z-statistics (placed in parenthesis in Table 2) in testing whether the estimate is statistically different from zero. Table 2 shows that based on a significance level of 0.05 , the test statistic needs to be greater than \pm 1.96 before the hypothesis that the estimate equals 0.00 can be rejected. Paths coefficients that are statistically significant $(\mathrm{p}<0.05)$ are indicated with stars. The model parameters reported in the figure 3 are the standardized path coefficients for the direct effects of one variable on the other. 


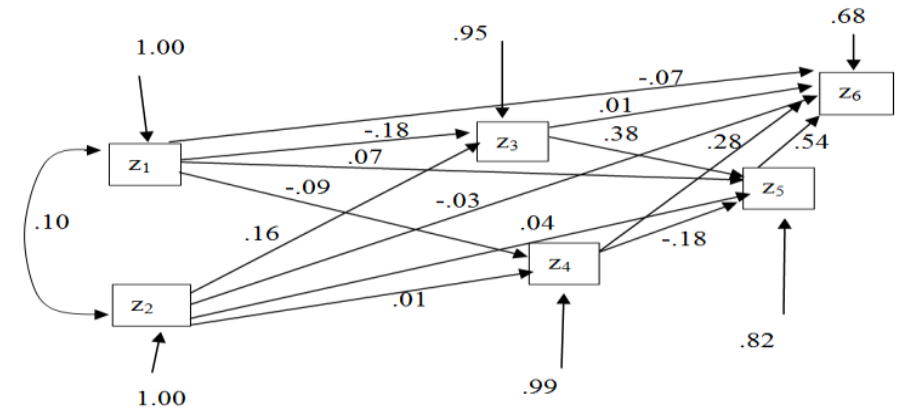

Figure 3: Structural equation model of the effects of environmental degradation, poverty, at home involvement, at school involvement proficiency in English Language and Mathematics

Table 2: Maximum Likelihood estimates for the model

\begin{tabular}{lcccccc}
\hline Paths & $\mathrm{DE}$ & $\mathrm{JE}$ & $\mathrm{TE}$ & $\mathrm{R}^{2}$ & $\mathrm{EV}$ \\
\hline To at home involvement & & & & & 0.05 & 0.95 \\
Environmental Degra. & $-0.18^{*}(2.71)$ & 0.00 & 0.00 & & \\
Poverty & $0.16^{*}(2.46)$ & 0.00 & 0.00 & & \\
To at school involvement & & & & & 0.99 & 0.01 \\
Environmental Degra. & -0.09 & $(1.34)$ & 0.00 & 0.00 & & \\
Poverty & 0.01 & $(0.18)$ & 0.00 & 0.00 & & \\
To English lang. Ach. & & & & & 0.18 & 0.87 \\
At home involvement & $0.38^{*}$ & $(5.89)$ & 0.00 & 0.39 & & \\
At school involvement & $-0.18^{*}(2.94)$ & 0.00 & -0.19 & & \\
Environmental Degra. & 0.07 & $(1.09)$ & 0.02 & 0.09 & & \\
Poverty & 0.04 & $(0.62)$ & 0.00 & 0.04 & & \\
To Mathematics Ach. & & & & & 0.32 & 0.66 \\
English lang. Ach. & $0.52^{*}$ & $(8.73)$ & 0.00 & 0.00 & & \\
At home involvement & 0.01 & $(0.11)$ & 0.21 & 0.22 & & \\
At school involvement & $0.28^{*}$ & $(4.89)$ & -0.10 & 0.18 & & \\
Environmental Degra. & -0.07 & $(1.26)$ & -0.04 & -0.11 & & \\
Poverty & -0.03 & $(0.55)$ & 0.00 & -0.03 & & \\
\hline
\end{tabular}

Note $=* \mathrm{p}<0.05 ;$ Number in parenthesis represent $\mathrm{z}$-score

$\mathrm{DE}=$ Direct Effect; IE = Indirect Effect; EV = Error Variance; $\mathrm{R}^{2}=$ Squared Multiple Correlation

\section{Indirect Effects}

Indirect effects are estimated statistically as the product of direct effects that comprise them. They are also interpreted as just as path coefficients. For example, the indirect effect of at-home parental involvement on mathematics achievement is estimated as the product of the standardized coefficients for the paths of "at-home parental involvement to English language achievement and English language achievement to mathematics achievement, or $(0.38)(0.54)=0.205$ (see figure 3$)$. The rationale for this derivation is as follows: At home parental involvement has a certain direct effect on English language achievement (0.38), but only part of this effect, (i.e. 0.54) of it is transmitted to mathematics achievement. The result, 0.205, say that Mathematics achievement is expected to increase by about 0.21 standard deviation for every increase in at-home parental involvement of one full standard deviation via its prior effect on English language.

The other direct effects as shown in table 2 were derived using the same logic.

\section{Discussion}

The findings of this study show that proficiency in English language and at-school parental involvement are among many predictors of primary school pupils' achievement in mathematics. In this study, these predictors had statistically significant direct effects on mathematics achievement. On the effect of proficiency in English language on mathematics achievement, the findings of this study is in line with the findings of other researchers such as Adegoke and Ibode, (2007) and Adegoke (2010) who found that proficiency in English language could predict mathematics achievement.

On the effect of at-school parental involvement on pupils' achievement in mathematics, the findings of this study is also consistent with other research findings from the different countries. For example, Lew (2007), in the United States of America, reported significant effects of parental involvement on mathematics and reading scores. In Nigeria, Olatoye and Agbatogun (2009) also reported that parental involvement is an important predictor of mathematics achievement. 
Further analysis showed that at-home involvement could, indirectly, through pupils' proficiency in the language of instruction, which in this study was English Language, affect pupils' achievement in Mathematics. In this study, after taking into account pupils' proficiency in English language, at-home parental involvement contributed to pupils' achievement in mathematics. This finding is not surprising taking into consideration that in the Niger Delta Region, "Pidgin English" which is a corrupt form of English language is the general language being spoken by almost $95 \%$ of the people. The use of "Pidgin English" both at home and at school may be of help to pupils in the Niger Delta have a fair grasp of the content of subjects being taught in school including mathematics.

The positive impact of the two dimensional aspects of parental involvement (i.e. at-school parental and at-home parental involvement) on achievement in English and Mathematics implies that parental involvement is a potent factor for predicting achievement. Hixson (2006) explained that involvement of parents and families is one of the ways to improve pupils' performance in academic work.

It is interesting to note that environmental degradation and poverty level had neither direct nor indirect effect on mathematics achievement and pupils' proficiency in English language. However, the analysis showed that there is significant negative correlation between environmental degradation and at home involvement (0.18). This implies that environmental degradation impacts negatively on the level of parental involvement in their children's education. This is in line with Opukri and Ibaba (20080 submissions that environmental degradation tends to reduce economic power of the parents. By reducing the economic power of the parents, also amounts to reducing the at-home parental involvement. The findings of this study showed a positive relationship between at-home parental involvement and poverty level. This finding suggests that poverty may after all be an incentive that can motivate parents to be involved in home based activities of their children. Poverty seems to be a propelling force that pushes parents to appreciate the value of education, set high educational aspirations for children and get involved intensively and consistently in the educational activities of their children.

The main inferences drawn from the findings of this study are that generally, parents are involved in the education of their children both at home and at school. Their at-home involvement has a positive and predictive influence on the children's achievement in English Language and indirect effect on Mathematics. Similarly, at-school parental involvement had direct effect on mathematics achievement of the pupils.

In the Niger Delta region, the environment is greatly devastated and this has adversely impacted on the livelihood of the people. As the findings of this study show, environmental degradation of Niger Delta Region might have reduced parents' level of at-home involvement in the education of their children.

\section{Conclusion}

This study has corroborated the need for parents to be involved actively in the education of their children. Therefore, it is recommended that school administrators and teachers should endeavour to create a welcoming environment for parents to be involved in the academic pursuit of their children. Activities that can improve atschool involvements, such as inviting parents during open days and of holding PTA meetings regularly should be vigorously pursued. More importantly schools should encourage parents to be more involved in the education of their children at home. This can be achieved by asking parents to sign the home work book of their children. Efforts should be geared towards reducing the degradation of the environment.

\section{References}

[1] Abd-El-Fattah, S.M. (2006). The relationship among Egyptian adolescents' perception of the parental involvement, academic achievement, and achievement goals: A mediational analysis. International Educational Journal 7, pp. 499-509.

[2] Adegoke, B.A. and Ibode, F.O. (2007). Knowledge of English language as a predictor of students' cognitive achievement in senior secondary school mathematics. African Journal of Cross-cultural psychology and sport facilitation, 9, pp. 80-84.

[3] Ekpenyong, O.A., Ukommi, A.S., \& Agha, E.O. (2010). Poverty: A potent conflict escalator in Nigeria's Niger Delta. Bangladesh Journal of Sociology, 7, pp. 33-41.

[4] Epstein, J. (2001). School, family and community partnerships. Boulder: Westview Press.

[5] Epstein, J. L., \& Sanders, M.G. (2000). Connecting home, school and community: New directions for social research. In M.T. Hallinan (Ed.) Handbook of the sociology of education. New York: Kluwer Academic P. Lenum publishers. pp. 285-306.

[6] Eregha P.B., \& Irughe, I.R. (2009). Oil induced environmental degradation in the Nigeria's Niger Delta: the Multiplier effects. Pennsylvania: Clarion University of Pennsylvania

[7] Faires, J., Nichols, W.D., \& Rickelman, R. (2000). Effects of parental involvement in developing competent readers in first grade. Reading Psychology, 21, pp. 195-215.

[8] Fakeye, D. O., \& Ogunsiji, Y. 2009. English Language proficiency as a predictor of academic achievement among EFL students in Nigeria. European Journal of Scientific Research, 37, pp. 490-495.

[9] Federal Republic of Nigeria (2004). National Policy on Education (4 ${ }^{\text {th }}$ edition) Abuja: NERDC.

[10] Federal Republic of Nigeria (2004). Universal Basic Education Act, Abuja: NERDC.

[11] Gianzero, G. (2001). Promoting Parental involvement improving student outcomes. A working paper prepared for San Diego Dialogue. Retrieved Feb 20, 2010, from http://www.sandiegodialogue.org/pdfs/parentalinvolvement.doc.pdf.

[12] Henderson, A. T. \& Mapp, K.L. (2002). A new wave of evidence: The impact of school, family and community connections on student achievement. Austin, IX: Southwest Educational Development Laboratory. 
[13] Hixon, J (2006). Critical Issues Supporting Ways Parents and Familiescan become involved in Schools. Cambridge: Harvard Family Research Project.

[14] Honig, M.I., Kahne, J. \& McLaughlin, M.W. (2001). School-community connections. Strengthening opportunity to learn and opportunity to teach. In V. Richardson (Ed.) Handbook of research on teaching, Washington DC: American Educational Research Association, pp.

[15] Howley, A. \& Maynard, S, (2006). Parent and Community Involvement on Rural Schools Educational Resource Information Centre (ERIC) US Department of Education.

[16] Ibaba, S.I. (2010). Environmental protection laws and sustainable development in the Niger Delta. Africana 4.1.

[17] Jordan, C., Orozco, E. \& Averret, A. 2001. Emerging issues in schools, family and community connections. Texas: Southwest Educational Development Laboratory.

[18] Jöreskog, K. \& Sörbom, D. (2006). LISREL 8.88 for Windows [Computer software] Lincolnwood, IL: Scientific Software International.

[19] Kloosterman, R., Notten, N., Tolsma, J., \& Kraaykamp, G. (2011). The effects of parental reading socialization and early school involvement on children's academic performances. A panel study of primary school pupils in the Netherlands. European Sociological Review, 27 (3), pp. 291- 306.

[20] Lew, N. (2007). The effects of parental involvement on student achievement: a fixed effects approach. University of California. Department of Education.

[21] National Examination Council (2008). Examiners' Report, Minna, Nigeria: NECO

[22] Oladejo, J. (1991). The national language Question in Nigeria: Is there an answer. Language Problem and Planning, 15, 255 -267

[23] Olatoye, R.A. \& Agbatogun, A. O. (2009). Parental involvement as a correlate of pupils' achievement in mathematics and science in Ogun State, Nigeria. Educational Research and Review 4, pp. 457-464.

[24] Omofonmwa, S.I. \& Odia, L. O. (2009). Oil exploitation and conflict in the Niger Delta region of Nigeria. Kamla-Raj Journal of Human Ecology, 26, pp. 25-30.

[25] Opukri, C.O. \& Ibaba, S.I. (2008). Oil induced environmental degradation and internal population displacement in the Nigeria's Niger Delta. Journal of Sustainable Development in Africa, 10, pp. 154-161.

[26] Starkey, P. \& Klein, A. (2000). Fostering parental support for children's mathematical development: An intervention with Head start families. Early Education and Development, 11, pp. 659 - 680.

[27] United Nations Development Report (2006). Niger Delta Development Human Report. Abuja: Nigeria.

[28] Van Voorhis, F.L. (2003). Interactive homework in middle school: Effects of family involvement and science achievement. Journal of Educational Research, 96, pp. 323-338.

[29] Williams, B., Williams, J., \& Williams, A. (2002). Parental Involvement in education (BMRB Social research). Norwich: Queen's Printer. 